\title{
ANALISIS KEPUASAN KONSUMEN TERHADAP BRAND SWITCHING BEHAVIOR MINUMAN TEH DALAM KEMASAN
}

\author{
Budi Susila ${ }^{\left.1,2^{*}\right)}$, Ujang Sumarwan ${ }^{3}$, Kirbrandoko $^{2}$ \\ ${ }^{1}$ PT Asahi Indofood Beverage Makmur, Sukabumi 43359, Indonesia \\ ${ }^{2}$ Program Pascasarjana Manajemen dan Bisnis, Institut Pertanian Bogor, Bogor 16151, Indonesia \\ ${ }^{3}$ Departemen IImu Keluarga dan Konsumen, Fakultas Ekologi Manusia, Institut Pertanian Bogor, \\ Bogor 16680, Indonesia \\ *)E-mail: budi.susila@ymail.com
}

\begin{abstract}
Abstrak
Penelitian ini bertujuan untuk menganalisis switching behavior konsumen minuman teh siap saji dalam kemasan. Switching behavior adalah bentuk loyalitas konsumen yang direpresentasikan dalam bentuk proporsi pembelian dalam kurun waktu tertentu. Penelitian ini mempelajari pengaruh dimensi bauran pemasaran terhadap kepuasan dan switching behavior konsumen. Metode penelitian menggunakan metode survei dan wawancara pengisian kuesioner dengan jumlah responden 154 orang berdasarkan metode quota sampling yang mana 40 persen responden berdomisili di Jakarta, 20 persen di Bogor, 20 persen di Tangerang, dan 20 persen di Bekasi. Variabel utama penelitian adalah kualitas produk, harga, ketersediaan, komunikasi dan reputasi merek. Variabel ini dianalisis dengan menggunakan analisis deskriptif dan Structural Equation Model (SEM). Hasil dari penelitian ini menunjukkan bahwa dimensi bauran pemasaran yang berpengaruh signifikan terhadap kepuasan konsumen adalah kualitas produk dan reputasi merek. Switching behavior konsumen produk teh dalam kemasan adalah switcher loyalty yang mana konsumen sebagian besar beralih ke merek lain saat merek yang diinginkan tidak tersedia.
\end{abstract}

Kata Kunci: kepuasan konsumen, minuman teh siap saji dalam kemasan, structural equation model, switching behavior

\section{Analysis of Consumer Satisfaction and Brand Switching Behavior of Ready to Drink (RTD) Tea}

\begin{abstract}
The objective of the study is to analyze the customer switching behavior of the ready to drink (RTD) tea. Switching behavior is a form of customer loyalty that reflects on proportion of purchase in certain period of time. This study aims to analyze the influence of marketing mix dimension on customer satisfaction and switching behavior. Data was collected by survey method and personal interview using questionnaire. The sample was selected by quota sampling method $(n=154,40$ percent from Jakarta, 20 percent from Bogor, 20 percent from Tangerang, and 20 percent from Bekasi). The variables of this research were marketing mix dimension, consisted of five aspects are product's quality, price, availability, products' communication, and brand reputation. The marketing mix dimensions were analyzed by descriptive analysis methods and Structural Equation Model (SEM) to examine its associate with satisfaction and switching behavior. The result showed that products' quality and brand reputation significantly associated with customer satisfaction. Switching behavior of ready to drink (RTD) tea conducted by consumer when there was no availibility of the desired brands.
\end{abstract}

Keywords: consumer satisfaction, packaged tea beverage, structural equation model, switching behavior

\section{PENDAHULUAN}

Kepuasan pelanggan adalah perasaan senang atau kecewa seseorang sebagai hasil dari perbandingan antara prestasi atau produk yang dirasakan dan yang diharapkannya (Kotler \& Keller, 2009). Tingkat kepuasan konsumen adalah salah satu faktor yang mampu memengaruhi loyalitas konsumen. Loyalitas konsumen juga dipengaruhi oleh kualitas servis, kepuasan konsumen dan image perusahaan (Adeleke \& Aminu, 2012). Hasil penelitian Djamaludin, Sumarwan \& Mahardikawati (2009) menunjukkan bahwa faktor yang mendasari tingkat kepuasan konsumen terhadap produk jamu gendong adalah kebersihan, karakteristik produk, karakteristik penjual, warna dan pelayanan penjual, keramahan dan daya tanggap penjual, dan bauran pemasaran. Kepuasan pelanggan 
akan berkorelasi positif terhadap loyalitas pelanggan tetapi berkorelasi negatif terhadap intention to switch (Mohzan et al., 2011). Suwarni \& Mayasari (2011) menyatakan bahwa kepuasan dan kualitas produk berpengaruh signifikan terhadap loyalitas konsumen, tetapi tidak dengan harga.

Loyalitas konsumen adalah isu yang sangat penting dan menarik bagi mereka yang berkecimpung dalam bidang pemasaran produk ataupun jasa. Loyalitas konsumen merupakan hal yang diinginkan setiap tenaga pemasaran karena konsumen yang loyal kepada suatu merek tidak hanya akan melakukan pembelian ulang, tetapi juga akan menambah volume atau frekuensi pembelian dan bahkan memberikan rekomendasi atau mengajak orang lain untuk ikut melakukan pembelian.

Salah satu bentuk loyalitas konsumen adalah switching behavior konsumen atau perilaku konsumen untuk beralih ke merek lain yang merupakan bentuk loyalitas konsumen yang dipresentasikan dalam bentuk proporsi pembelian. Beberapa penelitian mengenai switching behavior sebelumnya banyak dilakukan pada jasa atau produk yang memiliki barrier yang mudah dan berbiaya rendah. Penelitian yang dilakukan oleh Hendriks et al. (2009) yang meneliti switching behavior konsumen asuransi di Belanda dan menemukan bahwa perempuan yang sudah berusia lanjut memiliki pendidikan rendah dan bermasalah dengan kesehatannya memiliki kecenderunga berpindah merek yang lebih rendah. Sementara itu, Hermes et al. (2012) dalam penelitiannya tentangswitching behavior pengecer dan distributor beras di Tanzania menyimpulkan bahwa kredit perdagangan dapat menjadi switching barrier yang kuat bagi para pengecer dan distributor untuk berpindah. Hal ini juga menjadi indikasi lemahnya skema pembiayaan yang difasilitasi pemerintah.

Penelitian switching behavior di Indonesia sendiri belum pernah secara spesifik dilakukan, terutama untuk produk konsumen seperti minuman teh dalam kemasan. Banyaknya produk minuman teh dalam kemasan di pasaran tentu akan meningkatkan persaingan dan memudahkan konsumen untuk beralih ke merek lain. Adanya pengetahuan mengenai perilaku konsumen dalam menggunakan produk-produk minuman teh dalam kemasan terutama switching behavior tentu akan sangat membantu produsen dan tenaga pemasaran menentukan strategi yang tepat dalam memasarkan produk minuman teh dalam kemasan di pasar yang terus berkembang ini.
Menurut GAPMMI (Gabungan Pengusaha Makanan dan Minuman Indonesia), industri makanan, minuman \& tembakau tumbuh sebesar 9,19 persen di tahun 2012, setelah tahun sebelumnya hanya tumbuh 2,78 persen (GAPMMI, 2013). Komposisi persentase produk minuman itu terdiri dari air minum dalam kemasan 18 persen, teh siap minum 12 persen, minuman berkarbonat 10 persen, minuman berenergi 2,1 persen, minuman isotonik 1,5 persen, minuman sari buah 1,5 persen, dan sirup 1 persen. Dari data tersebut terlihat bahwa salah satu jenis produk yang menjadi primadona pertumbuhan tersebut adalah minuman ringan terutama teh siap saji. Tujuan dari penelitian ini adalah untuk mengidentifikasi karakteristik konsumen dalam hal perilaku konsumsi sesuai dengan penelitian Sari dan Retnaningsih (2008), tingkat kepuasan dan karakteristik switching behavior konsumen produk minuman teh dalam kemasan lalu merumuskan strategi pemasaran yang efektif berdasarkan data yang diperoleh.

\section{METODE}

Penelitian ini menggunakan desain cross sectional dengan metode survei. Penelitian ini dilaksanakan di wilayah Jabotabek dengan pertimbangan karena wilayah ini merupakan wilayah dengan jumlah penjualan terbesar produk minuman teh dalam kemasan di Indonesia. Penelitian dilakukan mulai bulan Desember 2013 sampai dengan Februari 2014.

Teknik penarikan contoh menggunakan metode quota sampling dengan melibatkan contoh sebanyak 154 orang. Contoh yang dipilih berasal dari wilayah Jabodetabek yang mana 40 persen responden dari Jakarta, 20 persen dari Bogor, 20 persen dari Tangerang, dan 20 persen dari Bekasi. Data primer diperoleh melaui pengisian kuesioner oleh konsumen yang pernah melakukan pembelian dan mengonsumsi produk minuman teh dalam kemasan merek $\mathrm{A}$ dan $\mathrm{B}$.

Data primer yang digunakan diantaranya demografi konsumen yang meliputi usia, jenis kelamin, tingkat pendidikan, pekerjaan utama, jumlah anggota keluarga, dan jumlah pengeluaran keluarga per bulan. Pada penelitian ini, dalam menganalisis kepuasan dan switching behavior konsumen menggunakan dimensi bauran pemasaran sebagai variabel eksogen. Penjelasan mengenai variabel eksogen dan variabel endogen beserta indikatornya dapat dilihat pada Tabel 1 . 
Pengukuran variabel-variabel pada Tabel 1 adalah dengan menggunakan skala jawaban Likert. Skala tersebut menggunakan lima pilihan sikap yang mana masing-masing pilihan tersebut menggambarkan tingkatan atau derajat sesuai dengan apa yang dirasakan oleh konsumen. Kelima tingkatan tersebut diantaranya adalah: 1 = "sangat tidak setuju", 2 = "tidak setuju", 3 = "ragu-ragu", 4 = "setuju", dan 5 = "sangat setuju". Selanjutnya, hasil penelitian ini dianalisis dengan menggunakan Stuctural Equation Modelling (SEM).

Tabel 1 Variabel eksogen dan endogen beserta indikatornya

\begin{tabular}{|c|c|}
\hline Variabel & Indikator \\
\hline \multirow[t]{3}{*}{ Variabel Eksogen Produk (६1) } & (X1): Citarasa teh dapat memenuhi keinginan konsumen \\
\hline & (X2): Aroma teh dapat memenuhi keinginan konsumen \\
\hline & (X3): Desain kemasan sangat menarik \\
\hline \multirow[t]{3}{*}{ Variabel Eksogen Harga (६2) } & (X4): Harga produk murah \\
\hline & (X5): Volume produk sesuai keinginan konsumen dan harga \\
\hline & (X6): Frekuensi diskon dan bonus saat pembelian \\
\hline \multirow[t]{3}{*}{ Variabel Eksogen Ketersediaan (६3) } & (X7): Produk selalu tersedia di toko/warung \\
\hline & (X8): Produk banyak tersedia dan mudah mendapatkan \\
\hline & $\begin{array}{l}\text { (X9): Produk dengan segera terlihat apabila tersedia di toko/ } \\
\text { warung }\end{array}$ \\
\hline \multirow{3}{*}{$\begin{array}{l}\text { Variabel Eksogen Komunikasi Konsumen } \\
(\xi 4)\end{array}$} & (X10): Iklan dan promosi sering muncul dan menarik \\
\hline & $\begin{array}{l}\text { (X11): Mudah mendapatkan informasi dan penjelasan mengenai } \\
\text { produk }\end{array}$ \\
\hline & (X12): Respon yang baik saat ada keluhan \\
\hline \multirow[t]{3}{*}{ Variabel Eksogen Reputasi Merek (६5) } & (X13): Saya yakin dengan reputasi merek A \\
\hline & (X14): Merek A berarti jaminan kualitas produk \\
\hline & (X15): Setiap orang sudah mengenal produk A \\
\hline Variabel Endogen Kepuasan ( $\eta 1$ ) & (X16): Kepuasan yang dicapai oleh konsumen \\
\hline $\begin{array}{l}\text { Variabel Endogen Switching Behavior } \\
(\mathrm{n} 2)\end{array}$ & $\begin{array}{l}\text { (Y1): Switching behavior konsumen }(\mathrm{n} 2) \text { terhadap produk dalam } \\
\text { bentuk undivided loyalty. }\end{array}$ \\
\hline
\end{tabular}

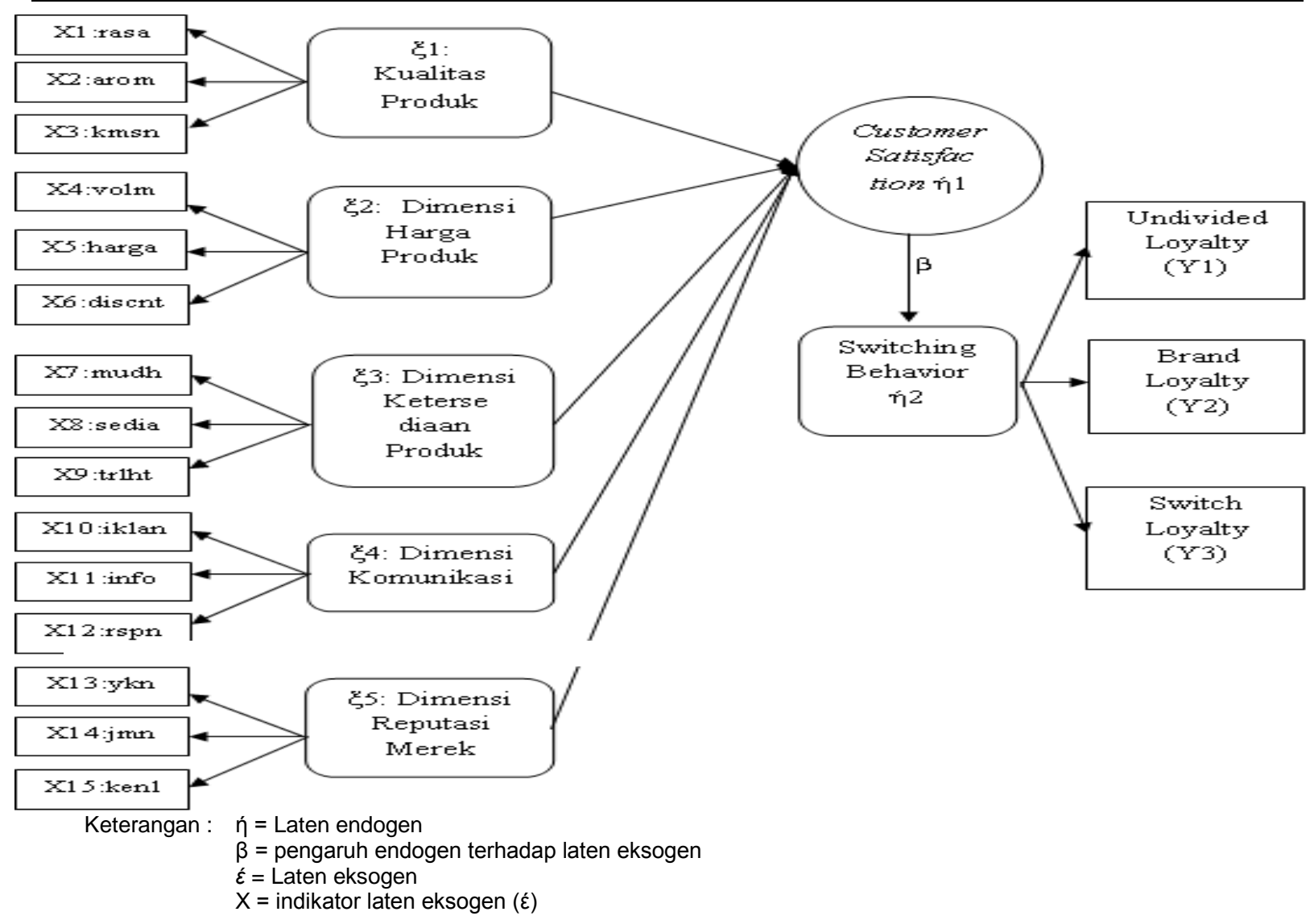

Gambar 1 Formulasi model SEM penelitian 


\section{HASIL}

\section{Demografi Konsumen}

Karakteristik konsumen yang ditelaah melalui analisis deskriptif tersebut diantaranya adalah usia, jenis kelamin, status pernikahan, tingkat pendidikan, pekerjaan utama, jumlah anggota keluarga, dan jumlah pengeluaran keluarga per bulan. Proporsi terbesar pada tiap karakteristik diperoleh melalui analisis deskriptif pada seluruh karakteristik konsumen dan dapat dilihat pada Tabel 2.

Hasil analisis deskriptif berdasarkan karakteristik demografi menunjukkan bahwa dari karakteristik usia yang mayoritas sebagai konsumen adalah pada rentang usia 20-29 tahun atau sebanyak 53,9 persen dengan mayoritas jenis kelamin adalah perempuan. Data di atas dapat dipergunakan sebagai data awal untuk menentukan strategi Segmenting, Targeting and Positioning (STP) dari sebuah strategi pemasaran yang akan diambil.

Selain demografi responden terdapat banyak faktor yang melatarbelakangi konsumen dalam mengonsumsi produk minuman teh dalam kemasan. Perilaku penggunaan ini diperlukan untuk menggambarkan bagaimana perilaku konsumen dalam mengonsumsi produk minuman teh dalam kemasan. Oleh sebab itu, penulis meminta responden untuk menjawab pertanyaan pada kategori usage sesuai dengan kebutuhan penelitian (Tabel 3).

\section{Karakteristik Responden Berdasarkan Perilaku Konsumsi}

Top of mind. Ingatan seseorang terhadap suatu produk secara spontan untuk pertama kalinya (top of mind) menunjukkan tingkat ketertarikannya terhadap produk tersebut dibandingkan dengan merek produk lain. Pada penelitian ini, responden diminta pendapatnya untuk mengingat sebuah produk minuman teh dalam kemasan. Korelasi pendapat responden tersebut dapat menjadi indikator seberapa besar kesan dan ingatannya terhadap produk merek minuman teh dalam kemasan. Dari 154 responden, ada 8 merek yang diingat responden sebagai merek produk minuman teh dalam kemasan yang pertama kali diingat. Sebanyak 93 orang $(60,4 \%)$ menyatakan A sebagai merek produk minuman teh dalam kemasan yang pertama kali diingat. Sebanyak 30 orang $(9,7 \%)$ mengingat $B, 15$ orang $(9,7 \%)$ mengingat $C, 7$ orang $(4,5 \%)$ mengingat $D$ dan sisanya adalah $\mathrm{E}$ sebanyak 4 orang $(2,6 \%), \mathrm{F}$ dan $\mathrm{G}$ masing-masing 2 orang $(1,3 \%)$ dan $\mathrm{H}$ sebanyak 1 orang $(0,6 \%)$.

Sumber informasi. Perbedaan sumber informasi yang didapatkan oleh konsumen akan memberikan pengaruh yang relatif berbedabeda sesuai dengan jenis produk dan ciri-ciri pembeli (Kotler \& Keller, 2009). Konsumen akan menerima informasi yang didapatkannya dan selanjutnya akan melakukan pemikiran yang matang tentang apakah sumber tersebut memiliki seluruh informasi yang cukup mewakili suatu produk atau jasa dan kebutuhan konsumen. Berdasarkan sumber informasi yang didapat konsumen akan memeringkatkan kebutuhan dan kemampuan konsumen sesuai dengan informasi yang ada pada sumber, kecocokan antara kebutuhan dan kemampuan dengan informasi yang didapat akan membentuk suatu maksud pembelian. Konsumen juga mungkin membentuk minat untuk memperdalam informasi mengenai produk atau jasa tersebut.

Hasil analisis menunjukkan bahwa responden lebih banyak mendapatkan informasi mengenai produk minuman teh dalam kemasan yang bersumber dari iklan TV $(59,1 \%)$, salesman sebesar $(30,8 \%)$, dari spanduk sebesar $(17,6 \%)$, dari teman sebesar $(13,2 \%)$, dari keluarga dan iklan media cetak sebesar $(3,3 \%)$ dan sumber informasi yang memiliki kontribusi terendah adalah melalui brosur sebesar $(1,1 \%)$ (Tabel 3). Tidak ada yang berpendapat mendapatkan informasi melalui website. Data ini menunjukkan bahwa iklan televisi menjadi media utama untuk melakukan promosi yang sangat efektif karena coverage cukup baik.

Tabel 2 Mayoritas konsumen berdasarkan karakteristik demografi

\begin{tabular}{llr}
\hline $\begin{array}{c}\text { Karakteristik } \\
\text { Demografi }\end{array}$ & \multicolumn{1}{c}{ Kategori } & Persentase \\
\hline Usia & $20-29$ & 53,9 \\
Jenis kelamin & Perempuan & 56,5 \\
$\begin{array}{l}\text { Status } \\
\text { pernikahan }\end{array}$ & Menikah & 52,6 \\
Tingkat & & 46,1 \\
Pendidikan & S1 & \\
Jenis & Karyawan & 50,6 \\
Pekerjaan & Swasta & 78,6 \\
Pendapatan & $<$ Rp5.000.000 & \\
Anggota & 4 Orang & 35,1 \\
Keluarga & < Rp2.000.000 & 59,7 \\
\hline Pengeluaran & &
\end{tabular}


Tabel 3 Karakteristik responden berdasarkan perilaku penggunaan (usage)

\begin{tabular}{|c|c|c|}
\hline Atribut/Kategori & Jumlah & Persentase \\
\hline \multicolumn{3}{|l|}{ Top of Mind } \\
\hline$A$ & 93 & 60,4 \\
\hline$B$ & 30 & 19,5 \\
\hline C & 15 & 9,7 \\
\hline D & 7 & 4,5 \\
\hline$E$ & 4 & 2,6 \\
\hline$F$ & 2 & 1,3 \\
\hline G & 2 & 1,3 \\
\hline $\mathrm{H}$ & 1 & 0,6 \\
\hline \multicolumn{3}{|l|}{ Sumber Informasi } \\
\hline Brosur & 1 & 0,6 \\
\hline Spanduk/reklame & 16 & 10,4 \\
\hline Teman & 12 & 7,8 \\
\hline Keluarga & 3 & 1,9 \\
\hline Salesman & 28 & 18,2 \\
\hline Media Cetak & 3 & 1,9 \\
\hline Website & 0 & 0 \\
\hline Iklan TV & 91 & 59,1 \\
\hline \multicolumn{3}{|l|}{ Alasan Membeli } \\
\hline Karena alasan haus & 106 & 68,8 \\
\hline Saat melihat produknya & 16 & 10,4 \\
\hline Karena ada discount & 2 & 1,3 \\
\hline $\begin{array}{l}\text { Sudah direncanakan } \\
\text { sebelumnya }\end{array}$ & 10 & 6,5 \\
\hline $\begin{array}{l}\text { Tidak direncanakan } \\
\text { sebelumnya }\end{array}$ & 16 & 10,4 \\
\hline Lainnya & 4 & 2,6 \\
\hline \multicolumn{3}{|l|}{ Lokasi Pembelian Teh } \\
\hline Supermarket & 59 & 38,3 \\
\hline Pasar/Toko Grosir & 2 & 1,3 \\
\hline Warung/Pinggir Jalan & 86 & 55,8 \\
\hline Lainnya & 7 & 4,5 \\
\hline \multicolumn{3}{|l|}{$\begin{array}{l}\text { Pertimbangan Saat } \\
\text { Pembelian }\end{array}$} \\
\hline Merek & 22 & 14,3 \\
\hline Harga & 21 & 13,6 \\
\hline Kemasan & 5 & 3,2 \\
\hline Rasa & 74 & 48,1 \\
\hline Kemudahan Memperoleh & 28 & 18,2 \\
\hline Volume/isi & 3 & 1,9 \\
\hline Lainnya & 1 & 0,6 \\
\hline \multicolumn{3}{|l|}{$\begin{array}{l}\text { Frekuensi Pembelian per } \\
\text { Minggu }\end{array}$} \\
\hline$<3$ kali & 102 & 66,2 \\
\hline 4 kali & 27 & 17,5 \\
\hline 5 kali & 8 & 5,2 \\
\hline$>5$ kali & 17 & 11,0 \\
\hline \multicolumn{3}{|l|}{$\begin{array}{l}\text { Saat Produk Tidak } \\
\text { Tersedia }\end{array}$} \\
\hline Mencari ke tempat Lain & 22 & 14,3 \\
\hline Mmbeli merek lain & 86 & 55,8 \\
\hline Membeli produk lain & 44 & 28,6 \\
\hline Lainnya & 2 & 1,3 \\
\hline
\end{tabular}

Alasan melakukan pembelian. Penelitian ini mencoba menggali informasi mengenai alasan responden melakukan pembelian dan konsumsi produk minuman teh dalam kemasan yang bertujuan agar produsen dan tenaga pemasaran memiliki data kapan dan bagaimana harus menciptakan kebutuhan akan pembelian produk teh dalam kemasan. Hasil analisis menunjukkan bahwa responden melakukan pembelian minuman teh dalam kemasan saat ada kondisi atau alasan tertentu seperti haus atau dalam perjalanan memiliki persentase terbesar yaitu sebesar 68,8 persen, membeli karena responden melihat produk tersebut sebesar 10,4 persen, tidak direncanakan sebelumnya juga 10,4 persen, karena sudah direncanakan sebelumnya sebesar 6,5 persen dan yang terendah yaitu karena ada discount atau bonus dengan persentase sebesar 1,3 persen.

Lokasi pembelian produk minuman teh dalam kemasan. Berdasarkan Tabel 3, dapat diketahui dimana biasanya responden membeli produk minuman teh dalam kemasan. Pada penelitian ini warung atau pinggir jalan menjadi lokasi utama responden mendapatkan produk minuman teh dalam kemasan dengan persentase sebesar 55,8 persen, berikutnya adalah supermarket dengan persentase 38,3 persen. Lokasi yang menjadi tempat membeli produk oleh responden yang terendah adalah pasar dengan persentase sebesar 1,3 persen.

Pertimbangan konsumen saat memutuskan pembelian. Pada Tabel 3 menunjukkan bahwa setiap konsumen memiliki alasan dan pertimbangan tertentu yang dapat berbedabeda saat membeli produk minuman teh dalam kemasan. Sebaran responden yang mempertimbangkan rasa produk pada saat memutuskan pembelian dengan persentase sebesar 48,1 persen, berikutnya adalah kemudahan mendapatkan dengan persentase sebesar 18,2 persen. Merek menjadi pertimbangan ketiga konsumen saat memutuskan pembelian dengan persentase 14,3 persen sedangkan volume menjadi hal yang paling tidak dipertimbangkan responden dengan persentase sebesar 1,9 persen.

Frekuensi pembelian. Berdasarkan Tabel 3 terlihat bahwa sebagian besar responden pada penelitian ini membeli produk minuman teh dalam kemasan kurang dari 3 kali dalam satu minggu dengan persentase 66,2 persen. Sebanyak 17,5 persen responden menyatakan membeli produk minuman teh dalam kemasan 4 kali dalam satu minggu, 11 persen lebih dari 5 kali dalam satu minggu dan yang terkecil 
dengan 5,2 persen sebanyak 5 kali dalam satu minggu.

Sikap konsumen saat produk yang dibeli tidak tersedia. Pada saat responden membeli suatu merek tertentu produk minuman teh dalam kemasan dan ternyata di lokasi pembelian produk tersebut tidak tersedia, baik itu habis ataupun belum menjual, maka sikap konsumen yang diputuskan akan menjadi bahan informasi yang penting bagi tenaga pemasaran terutama dalam hal loyalitas dan switching behavior konsumen. Pada penelitian ini, sebesar 55,8 persen responden menyebutkan bahwa akan membeli produk dari merek yang lain apabila produk yang diinginkan tidak tersedia. Sebanyak 28,6 persen responden menyebutkan akan membeli produk lain selain minuman teh dalam kemasan yang seluruhnya menyebutkan air mineral (air minum dalam kemasan) yang produk substitusinya dan hanya 14,3 persen responden yang menyatakan akan pergi ke tempat lain untuk tetap mencari merek produk yang dicari.

\section{Analisis Switching Behavior Konsumen}

Switching behavior konsumen suatu produk merupakan salah satu bentuk manifestasi loyalitas konsumen. Dalam penelitian ini, kategori switching behavior konsumen didefinisikan menjadi tiga kategori yaitu undivided loyalty, brand loyalty, dan switcher loyalty.
Analisis lebih lanjut dari penelitian ini adalah dengan menggunakan tabulasi silang untuk melihat seberapa banyak responden yang termasuk kelompok undivided loyalty, brand loyalty dan switcher loyalty. Kecenderungan konsumen untuk beralih merek produk minuman teh dalam kemasan ini kemudian dikelompokkan berdasarkan kelompok atau tipe switching behavior. Hasil analisis deskriptif pada seluruh responden tersebut dapat dilihat pada Tabel 4.

Tabel 4 Switching behavior konsumen minuman teh dalam kemasan

\begin{tabular}{lr}
\hline \multicolumn{1}{c}{ Tipe Switching Behavior } & Persentase \\
\hline Undivided loyalty (AAAAA) & 3,2 \\
Brand Loyalty (AAABB) & \\
1. AAAAB & 1,9 \\
2. AAAAB 1 & 4,5 \\
3. AAABB & 1,3 \\
4. AAABB ${ }_{1}$ & 9,7 \\
5. AAAB ${ }_{1} B_{1}$ & 6,5 \\
Sub Total & 24,0 \\
\hline Switcher Loyalty (AABBB) & \\
1. AA BBB & 2,6 \\
2. AA BBB $B_{1}$ & 13,0 \\
3. AA BB ${ }_{1} B_{1}$ & 27,3 \\
4. AA B ${ }_{1} B_{1} B_{1}$ & 29,9 \\
Sub Total & 72,7 \\
\hline Keterangan:
\end{tabular}

Keterangan:

$A=$ Teh merek $A, B=$ Teh merek $B, B_{1}=$ Merek minuman teh lain

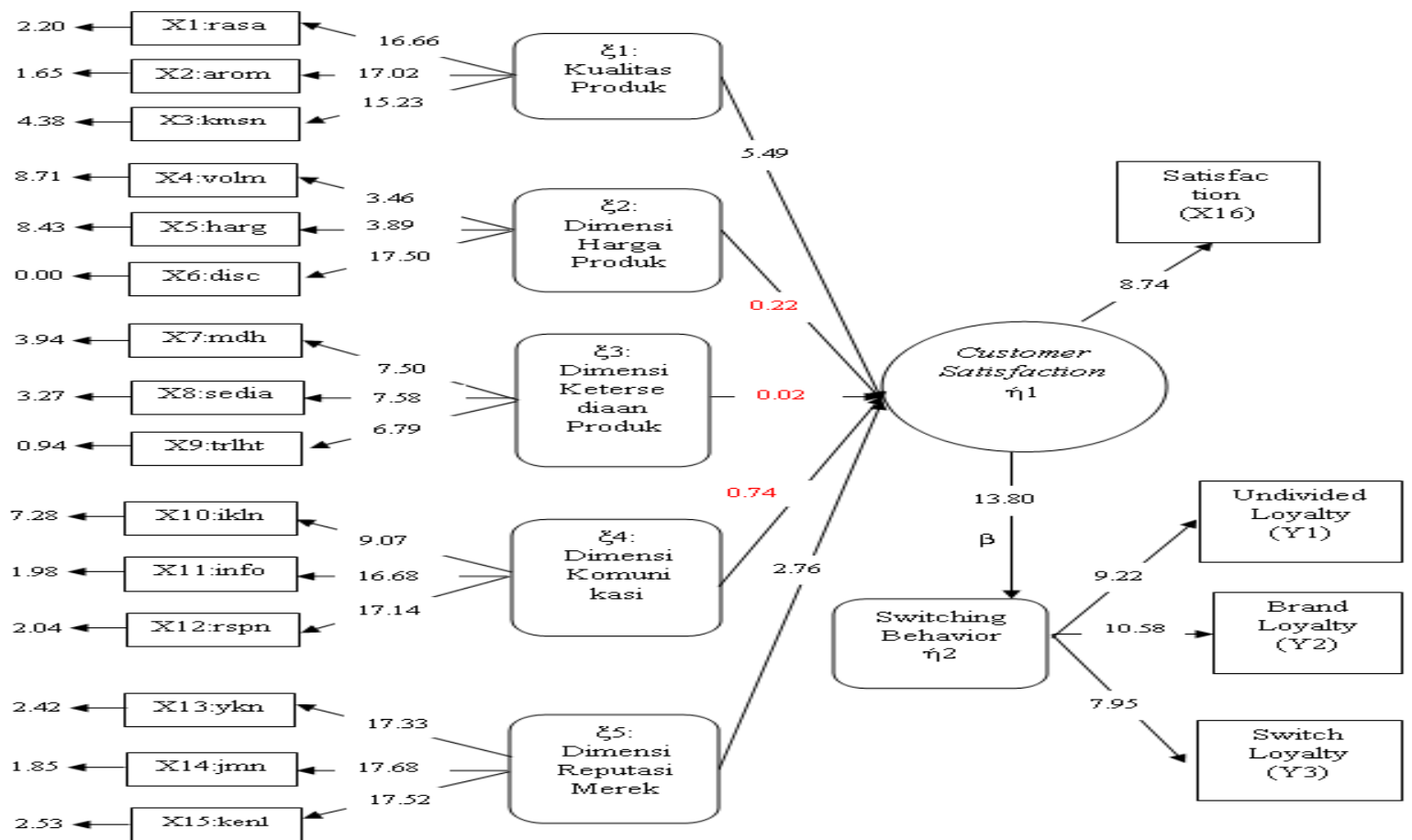

Gambar 2 Hasil uji t-hitung produk B 
Undivided loyalty adalah impact dari loyalitas konsumen yang tercermin dalam brand switching behavior AAAAA. Atribut ini menunjukkan bahwa konsumen hanya membeli produk $A$ dalam lima kali pembelian terakhir. Pada penelitian ini, hanya 3,25 persen responden yang tergolong dalam tipe switching behavior undivided loyalty.

Brand loyalty merupakan impact dari loyalitas konsumen yang tercermin dalam brand switching behavior $A A \mathrm{AB}_{1} \mathrm{~B}_{1}, \mathrm{AAAB}_{1}, \mathrm{AB}_{1} \mathrm{AB}_{1} \mathrm{~A}$, $B_{1} A B_{1} A A$ atau ada unsur $A$ minimal tiga kali dalam lima kali pembelian terakhir. Atribut ini menunjukkan bahwa konsumen pernah membeli produk lain selain A dalam lima kali pembelian terakhir. Dalam penelitian ini, persentase responden yang tergolong dalam kategori ini sebesar 24,0 persen.
Produk B pada Gambar 3, variabel indikator $X 1$ sampai $X 16$ memiliki nilai uji-t yang lebih besar dari 1,96 kecuali variabel harga $(0,22)$, variabel ketersediaan $(0,02)$ dan komunikasi $(0,74)$ tidak signifikan berpengaruh terhadap kepuasan. Kepuasan pelanggan produk $B$ dipengaruhi secara signifikan oleh variabel laten eksogen kualitas produk dengan nilai t-hitung 5,49 dan reputasi merek dengan nilai t-hitung 2,76. Untuk indikator Y1 sampai dengan $Y 3$ mempunyai nilai uji-t lebih besar dari 1,96. Baik variabel indikator $X$ dan variabel indikator $Y$ yang memiliki nilai uji-t yang lebih besar dari 1,96 tersebut menjelaskan hubungan yang signifikan dengan masing-masing variabel laten.

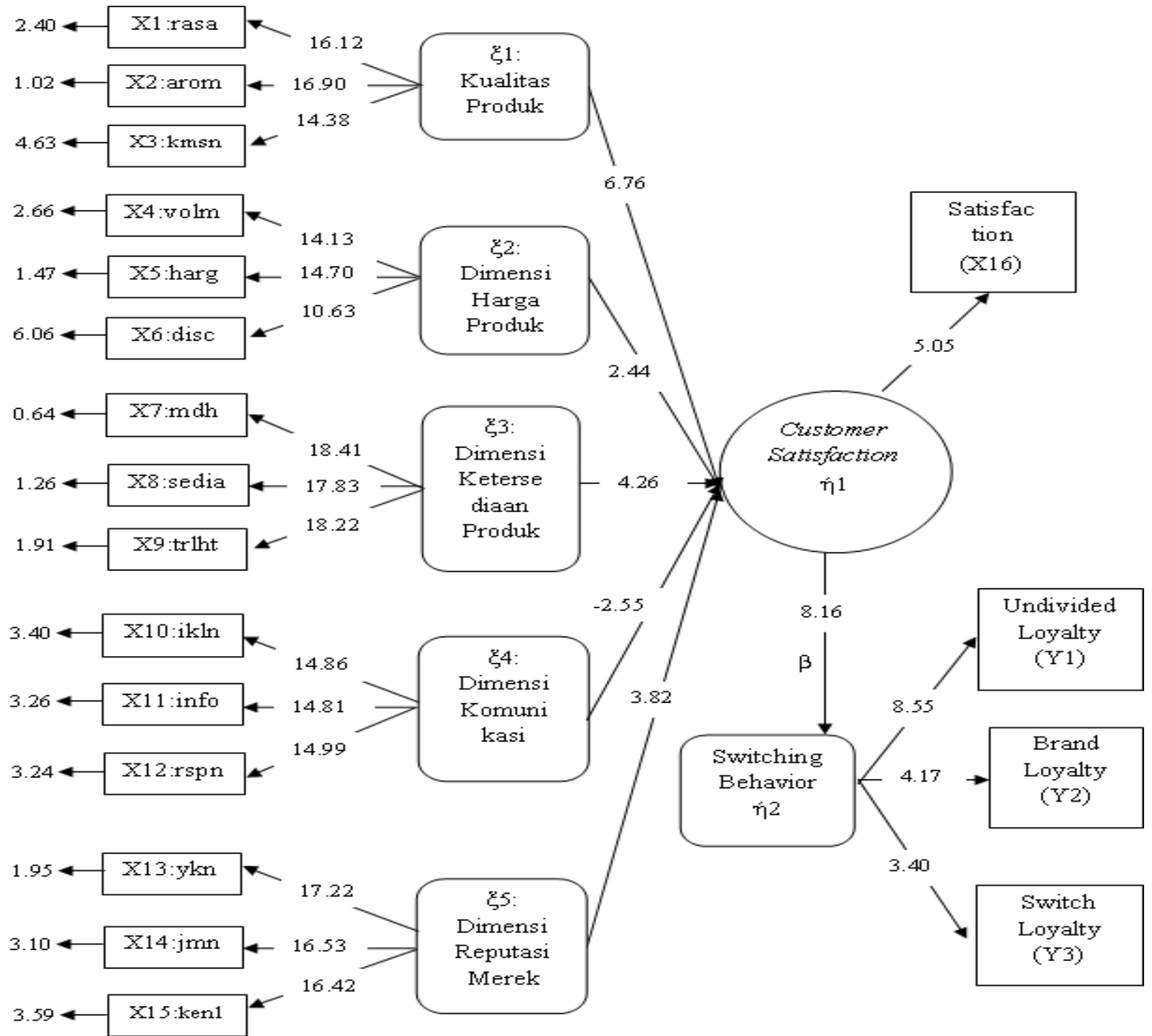

Gambar 3 Hasil uji t-hitung produk B 


\section{PEMBAHASAN}

Berdasarkan hasil analisis deskriptif perilaku penggunaan (usage) diketahui bahwa produk A masih menjadi top of mind saat konsumen diminta mengingat produk minuman teh dalam kemasan. Pada umumnya responden mengetahui informasi tentang produk dari iklan di televisi $(59,1 \%)$ dan membeli pada saat haus $(68,8 \%)$ di warungwarung pinggir jalan. Hal tersebut menunjukkan bahwa iklan yang paling efektif adalah melalui media above the line yaitu media televisi, jalur distribusi yang harus diperkuat adalah jalur pemasaran tradisional dengan memastikan ketersediaan di warung-warung terutama di area dimana ada kemungkinan konsumen merasa haus, misalnya di lokasi olahraga, tempat wisata, dan sekolah-sekolah. Berdasarkan sisi produk, aroma dan rasa harus memiliki keunggulan dan keunikan. Ketersediaan produk juga menjadi penting karena ketika produk tidak tersedia, konsumen dengan cepat akan beralih dan beralih ke merek lain yang mereka inginkan.

Hasil analisis SEM menunjukkan bahwa dimensi kualitas produk (₹1) yang memberikan pengaruh paling besar terhadap kepuasan baik untuk produk A sebagai benchmarking maupun produk B. Dimensi kualitas produk (₹1) tercerminkan melalui ketiga indikatornya bahwa kontribusi variabel indikator terbesar terhadap dimensi kualitas produk adalah cita rasa dan aroma produk yang memiliki nilai yang hampir sama (Gambar 2 dan Gambar 3). Penelitian ini mendukung hasil penelitian sebelumnya bahwa diantara kualitas produk dan harga, hanya kualitas produk yang memengaruhi loyalitas konsumen (Suwarni \& Mayasari, 2011). Menurut Clemes, Gan, \& Zheng (2007) kualitas merupakan salah satu faktor yang dapat membuat seseorang tetap bertahan atau beralih kepada merek lain. Oleh karena itu, dimensi kualitas produk harus terus diperhatikan oleh manajemen karena variabel kualitas dan indikator-indikatornya memberikan pengaruh yang paling besar dalam membangun kepuasan konsumen. Hal ini dapat dilakukan oleh perusahaan dengan membuat sistem jaminan mutu yang baik dan terjaga serta membekali karyawan kemampuan untuk menjaga bahkan meningkatkan kualitas produk. Manajemen dapat meningkatkan kemampuan karyawannya dengan memberikan pelatihan yang diberikan oleh pihak eksternal yang kompeten dibidang kualitas untuk mempertajam kompetensi para karyawannya.
Dimensi bauran pemasaran lainnya yang perlu diperhatikan adalah reputasi merek (\$5). Menurut Samuel dan Fudjiawati (2005) dalam hasil penelitiannya bahwa kepuasan konsumen dan kesetiaan merek memiliki hubungan positif signifikan. Manajemen harus mampu membuat program pemasaran yang mampu meyakinkan konsumen bahwa kualitas produk yang dihasilkan adalah yang terbaik, terjamin kualitasnya dan mampu memenuhi ekspektasi konsumen. Mengingat bahwa karakteristik produk, pelayanan, dan faktor bauran pemasaran yang mendasari tingkat kepuasan konsumen terhadap produk (Djamaludin, Sumarwan, \& Mahardikawati, 2009). Dalam hal kemudahan mendapatkan informasi, salah satu cara yang bisa dilakukan adalah dengan menggali lebih dalam penggunaan dunia maya sebagai media promosi.

Pada kontribusi variabel indikator pembangun loyalitas, manajemen perusahaan perlu lebih memperhatikan tingginya variabel switcher loyalty (Y3). Indikator switcher loyalty merupakan indikator yang dianggap penting dikarenakan konsumen walaupun merasa telah mendapatkan kepuasan dari produk lama $A$ tetapi akan dengan mudah untuk beralih switching ke produk lain apabila ketersediaannya terganggu atau terdistorsi oleh iklan yang menarik. Setelah konsumen bersedia beralih, pihak manajemen perlu menjaga dan meningkatkan kepuasan konsumen yang telah bersedia beralih ini agar merasa puas dengan kualitas produk yang diterima sehingga konsumen bersedia untuk melakukan pembelian ulang bahkan merekomendasikan produk kepada orang lain. Manajemen juga harus mengubah kebijakan yang mengatur sistem pemasaran dan distribusi dengan meningkatkan ketersediaan dan visibility produk di jaringan distribusi agar konsumen mudah memperoleh produk kita.

\section{SIMPULAN DAN SARAN}

Berdasarkan hasil penelitian dan berbagai analisis diatas, maka dapat diambil simpulan bahwa pengujian model pengaruh lima dimensi bauran pemasaran melalui 15 variabel indikator dalam membentuk kepuasan konsumen dengan menggunakan analisis SEM menghasilkan dua dimensi pelayanan yang dianggap penting oleh konsumen minuman teh dalam kemasan dalam memengaruhi kepuasan, yaitu dimensi kualitas produk dan reputasi merek. Tingkat kepuasan konsumen terhadap produk yang telah lama beredar di pasaran seperti produk $A$ ternyata tidak lebih tinggi dari produk pendatang baru seperti produk $B$. 
Pada penelitian ini karakteristik switching behavior konsumen yang paling dominan adalah perilaku konsumen switcher loyalty. Konsumen minuman teh dalam kemasan cenderung tidak loyal terhadap merek minuman teh tertentu dan dengan mudah beralih ke merek lain saat produk yang diinginkan tidak tersedia.

Terdapat tiga upaya yang dapat diterapkan dalam strategi pemasaran, upaya tersebut mengacu kepada hasil yang diperoleh pada implikasi manajerial, yaitu: (1) manajemen perlu membenahi kemampuan meningkatkan dan mempertahankan kualitas dengan menjalankan program jaminan mutu dalam rantai produksinya dan memberikan training yang memadai terkait mutu kepada seluruh jenjang karyawan, (2) mengintensifkan iklan melalui televisi sebagai sarana berkomunikasi dengan konsumen seraya mendengarkan aspirasi konsumen tentang mutu produk yang diinginkan, (3) meningkatkan reputasi merek dengan mendirikan layanan call center untuk memberikan informasi pada konsumen serta menangani keluhan yang ada, (4) memastikan ketersediaan produk terutama di area-area dimana konsumen membutuhkan produk minuman teh dalam kemasan.

\section{DAFTAR PUSTAKA}

Adeleke, A., \& Aminu, S. A. (2012). The determinants of customer loyalty in Nigeria's GSM market. International Journal of Business and Social Science, 3(14), 209-222.

Clemes, M. D., Gan, C., \& Zheng, L. Y. (2007). Costumer switching behavior in the New Zealand banking industry. Journal Banks and Banks Systems, 2(4), 50-65.

Djamaludin, M. D., Sumarwan, U., \& Mahardikawati, G. N. A., (2009). Analisis kepuasan dan loyalitas konsumen jamu gendong di Kota Sukabumi. Jur. IIm. Kel. \& Kons., 2(2), 175-185.

[GAPMMI] Gabungan Pengusaha Makanan dan Minuman Indonesia. (2013). Informasi pertumbuhan industri makanan, minuman dan tembakau. Diambil dari http://www. gapmmi.or.id/?pilih=lihat\&id=13417. [diunduh 19 Mei 2013].

Hendriks, M., De Jong, J. D., den Brink-Muinen, A., \& Groenewegen, P. P. (2009). The intention to switch health insurer and actual switching behavior: Are there differences between groups of people?. health expectation journal. Journal Compilation Blackwell Publishing Ltd.,3 (1),195-207.doi:10.1111/j.13697625.2009. 00583.x.

Hermes, N., Kihanga, E., Lensink, R., Lutz, C. (2012). The impact of trade credit in costumer switching behavior: Evidence from the Tanzanian rice market. Journal of Development Studies, 48(3), 363-376.

Kotler, P., \& Keller, L. K. (2009). Manajemen pemasaran. Jakarta, ID: Erlangga.

Mohzan, F., Nawas, M. M., Khan, M.S., Shaukat, Z., \& Aslam, N. (2011). Impact ofcustomer satisfaction on customer loyalty and intentions to switch: Evidence from banking sector of Pakistan. International Journal of Business and Social Science, 2(16), 263-270.

Sari, M. N., \& Retnaningsih. (2008). Perilaku konsumsi ibu hamil. Jur. Ilm. Kons. \& Kel., 1(1). 87-96.

Samuel, H., \& Fudjiawati. (2005). Pengaruh kepuasan konsumen terhadap kesetian merek. Jurnal Manajemen dan Kewirausahaan, 7(1), 74-82.

Suwarni, \& Mayasari, S. D. (2011). Pengaruh kualitas produk dan harga terhadap loyalitas melalui kepuasan konsumen. Jurnal Ekonomi Bisnis, 16(1), 76-84. 